\title{
K. Subramanya Sastry: Plant virus and viroid diseases in the tropics, Volume 1: Introduction of plant viruses and sub-viral agents, classification, assessment of loss, transmission, and diagnosis
}

\author{
Springer, New Delhi
}

\section{Teruo Sano ${ }^{1}$}

Received: 4 June 2015/Accepted: 9 June 2015/Published online: 20 November 2015

(C) Indian Virological Society 2015

Throughout the world, most of the plants are naturally affected by number of virus and viroid diseases, besides fungal and bacterial pathogens. Virus and viroid diseases are economically important because of the losses they cause in productivity and quality of the plant products. The profitable crop production depends on the appropriate diagnosis of the etiological agents and application of management measures.

In the first volume, the author Dr. K Subramanya Sastry, has provided up-to-date information on different aspects of plant virus and viroid diseases of crop plants of South East Asia, Africa, South American countries in five chapters, which are interlinked and exhaustive. Detail information on classification, crop yield losses, transmission and diagnosis of virus and viroid diseases at advanced as well as comprehensive level has been described.

In the introductory chapter, the author has presented the information on tropical countries, their climate, tropical crops and the prevalent virus and viroid diseases. The second chapter is focused on introduction of virus and virus-like diseases and their classification based on the 9th report of ICTV published by King et al. (2012). In the third chapter, the author has provided the extensive yield losses both quantitatively and qualitatively in large number of crops due to virus and viroid infections. Viruses cause their damage in such diverse ways like reducing the vigor and life span of the infected plants of the orchards, groves and pastures. In the fourth chapter, Dr. Sastry, has discussed the different agents and factors involved in the spread of virus and viroid diseases, which are very much required for framing suitable management measures. The author has also provided exhaustive information on seed transmission of plant virus and viroid diseases which would be quite useful to the personnel involved at quarantine and agriculture. The fifth chapter describes the diagnosis and detection of plant virus and viroid diseases by the application of techniques including the electron microscopy, serological techniques like variants of ELISA, monoclonal antibody techniques, nucleic acid hybridization technologies, PCR/RT-PCR, microarray technologies, biosensors, etc., which are the outcome of number of years of hard work in different research laboratories at global level. The diagnostic techniques which are sensitive, rapid and accurate in virus and viroid diagnosis are provided.

This volume 1 will serve as one of the valuable and comprehensive reference book for the basic, practical and applied plant pathologists, scientists, teaching faculty and researchers of plant virology, plant pathology and plant biology. This volume is relevant and timely in view of the rapidly expanding international trade of plant and plant products. The author, Dr. K Subramanya Sastry, has done sincere hard work and major efforts to provide the latest information and it is my pleasure to complement him, for his outstanding and comprehensive volume 1 on plant virus and viroid diseases in the tropics.

Teruo Sano

sano@cc.hirosaki-u.ac.jp

1 Department of Plant Pathology, Faculty of Agriculture and Life Science, Hirosaki University, 3 Bunkyo-cho, Hirosaki 036-8561, Japan 